\title{
ANALISIS HUKUM PELANGGARAN HAK EKONOMI DI BIDANG PENYIARAN DENGAN SENGAJA DAN TANPA HAK YANG DILAKUKAN DIREKTUR PERSEROAN TERBATAS (STUDI PUTUSAN No 193/PID.SUS/2019/PN.TTe)
}

\author{
Teguh Arido Sitompul, Jinner Sidauruk, Hisar Siregar \\ Fakultas Hukum, Universitas HKBP Nommensen \\ jinnersidauruk@uhn.ac.id
}

\begin{abstract}
Abstrak
Dalam suatu ciptaan atau hasil karya ciptaan terkandung hak siar eksklusif untuk menyiarkan semua pertandingan Piala Dunia. Di dalam hak siar eksklusif juga terkandung hak ekonomi yang dimiliki si pencipta. Pelanggaran hak siar oleh perusahaan adalah dengan menyiarkan pertandingan sepakbola tanpa izin sipemegang hak siar eksklusif melalui TV kabel. Pasal 82 UU Nomor 40 Tahun 2007 (PT) menyebutkan Direktur mewakili Perseroan keluar dan kedalam. Dalam hal PT melakukan pelanggaran tindak pidana sebagaimana bahwa yang mewakili perseroan di depan pengadilan adalah direktur. Jenis penelitian yang digunakan adalah penelitian hukum normatif dengan cara menelusuri atau menelaah dan menganalisis bahan pustaka, seperti Putusan No 193. Pid.Sus/2019/PN TTe. Berdasarkan hasil penelitian Putusan No 193.Pid.Sus/2019/PN TTe diperoleh kesimpulan bahwa perbuatan Direktur PT. Bintang Kejora Cable telah memenuhi unsur dengan sengaja dan tanpa hak melakukan pelanggaran hak ekonomi, sehingga pertanggungjawaban pidana dapat dimintakan kepada Direktur Perseroan Terbatas. Berdasarkan hal tersebut hakim menjatuhkan hukuman selama 1 (satu) Tahun 6 (enam) bulan penjara dan denda sejumlah Rp 1.000.000.000 (satu milyar rupiah) sebagai bentuk pertanggungjawaban pidana kepada Direktur PT. Bintang Kejora Kable
\end{abstract}

\section{Kata Kunci : Analisis hukum, Pelanggaran, Hak Ekonomi, Penyiaran, Direktur}

\begin{abstract}
A work or creation contains exclusive broadcast rights to broadcast all World Cup matches. The exclusive broadcasting rights also contain economic rights which are owned by the creator. Broadcast rights violations by the company are broadcasting football matches without the permission of the exclusive broadcast rights holder via cable TV. Article 82 of Law Number 40 of 2007 (PT) states that the Director represents the Company going out and in. In the event that a PT commits a criminal offense, as that which represents the company before the court is the director. The type of research used is normative legal research by tracing or analyzing and analyzing library materials, such as Decision No. 193. Pid.Sus / 2019 / PN TTe. Based on the results of research on Decision No. 193Pid.Sus / 2019 / PN TTe, it was concluded that the actions of the Director of PT. Bintang Kejora Cable has fulfilled the elements of deliberately and without rights violating economic rights, so that criminal liability can be brought to the Director of a Limited Liability Company. Based on this, the judge sentenced him to 1 (one) year 6 (six) months imprisonment and a fine of Rp. 1.000.000,000 (one billion rupiah) as a form of criminal responsibility to the Director of PT. Morning Star Kable
\end{abstract}

Keywords: Law Analysis, Violation, Economic Rights, Broadcasting, Director 


\section{Pendahuluan}

Indonesia merupakan negara yang kaya akan kekayaan intelektual, diantaranya adalah hak cipta sebagai milik perorangan yang bersifat immaterial dan merupakan hak kebendaan. Ciptaan merupakan hasil karya pencipta dalam lapangan ilmu pengetahuan, seni dan sastra. Hak cipta sebagai hak kebendaan immaterial diberikan perlindungan hukum dari hak kekayaan intelektual yang merupakan sistem kepemilikan dalam bentuk penghargaan (reward) atau ekspresi kepribadian atau perangsang (incentive) bagi pencipta, inventor atau pendesain atas pengorbanannya dalam menghasilkan kreasi intelektual yang memiliki nilai finansial yang signifikan ${ }^{1}$

Hal ini membuktikan bahwa hak cipta merupakan hak yang dapat dimiliki oleh perorangan yang secara yuridis dan berlaku syarat-syarat kepemilikan, baik mengenai cara penggunaannya maupun cara pengalihan haknya. Pasal 1 ayat (1) UU 28 Tahun 2014 tentang Hak Cipta, menyebutkan bahwa, "hak cipta merupakan hak eksklusif bagi pencipta atau pemegang hak cipta untuk mengumumkan atau memperbanyak ciptaannya, yang timbul secara otomatis setelah suatuiptaan dilahirkan tanpa mengurangi pembatasan menurut peraturan perundang-undangan yang berlaku". Selanjutnya rumusan Pasal 1 ayat 1 UU No 28 tahun 2014 tentang Hak cipta terkandung hak ekonomi bahwa si pencipta dapat memberikan haknya kepada pihak lain untuk memperbanyak hasil ciptaannya melalui perjanjian. Berdasarkan perjanjian tersebut maka si pemilik hak cipta akan dapat memperoleh keuntungan.

Hak ekonomi adalah hak yang dimiliki oleh seorang pencipta untuk mendapat manfaat ekonomi atas ciptaannya. Hak ekonomi meliputi hak siar, hak reproduksi, hak distribusi, hak adaptasi dan hak pertunjukan. Untuk memanfaatkan nilai ekonomi yang terkandung dalam hak tersebut, sering kali pemegang hak cipta diperbolehkan untuk memberikan hak ekonomi secara sebagian maupun secara keseluruhan. ${ }^{2}$ Namun pada tahap ini sering terjadi pelanggaran baik itu hak cipta berupa pelanggaran hak ekonomi si pencipta misalnya seperti melakukan penayangan siaran tanpa izin, terutama dalam hal eksplorasi yang dilakukan oleh perusahaan-perusahaan besar yang mengakut para jajaran direksi perusahaan untuk meraup keuntungan sebanyak-banyaknya tanpa memberi dampak ekonomis bagi si pencipta.

Menteri Hukum \& HAM Yasonna Laoly mengatakan pihaknya telah menerima 125.785 permohonan yang meliputi Merek, Hak Cipta, Paten, Desain Industri dan Indikasi geografis, naik dari 199 ribu permohonan. Secara rinci permohonan kasus hak cipta sebanyak 36.522 permohonan, Tahun 2019 Kementerian Hukum dan Hak Asasi Manusia (disingkat Kemenkumham) telah menerima pengaduan pelanggaran hak cipta 7 (tujuh) kasus, selanjutnya Tahun 2019 Direktorat Jendral Kekayaan Intelektual menerima 47 aduan pelanggaran kekayaan intelektual. ${ }^{3}$

Salah satu kasus yang di analisis adalah putusan No 193.Pid.Sus/2019/PN Ternate yaitu PT. Digital Vision Nusantara (K-Vision) merupakan Perseroan Terbatas sebagai pemilik sub-lisensi Piala Dunia 2018, dan berhak atas beberapa hak media terkait pertandingan sepak bola tersebut, sebagai pemegang lisensi PT Digital Vision Nusantara (K-Vision) berhak untuk menjalankan sendiri maupun menjual hak-hak media melalui

\footnotetext{
${ }^{1}$ Rahmi Jened Parinduri Nasution, Interface Hukum Kekayaan Intelektual dan Hukum Persaingan Penyalahgunaan HKI, Jakarta, Raja Grafindo Persada, 2013, hal 6.

${ }^{2}$ Henry Soelistiyo, Hak Cipta Tanpa Hak Moral, Jakarta: PT. RajaGrafindo Persada 2011, hal.6465.

${ }^{3}$ Andry Novelino, Pelanggaran Merek Paling Banyak Diadukan ke kemenkumham, Cnn, 1 Januari 2020. Diakses pada 12 Agustus 2020 di laman http://m.cnnindonesia.com/teknologi/20191231141341-185461331/pelanggaran-merek-palin-banyak-diadukan-ke-kemenkumham
} 
perjanjian sub-lisensi kepada perusahaan sponsor, atau lembaga penyiaran atau pihak lainnya dengan ketentuan yang telah disepakati oleh kedua pihak, dengan demikian PT Digital Vision Nusantara sebagai pemegang hak cipta berhak mendapat royalti juga berhak melarang pihak lain menggunakan ciptaan secara komersial tanpa izin. Tahun 2019 ditemukan pihak lain yang melakukan siaran piala dunia 2018 secara komersial tanpa izin dari PT. Digital Vision Nusantara (K-Vision),Pihak tersebut adalah Direktur PT. Bintang Kejora Cable Vision telah mempromosikan, mengumumkan, menginformasikan kepada khalayak umum,dengan menggunakan alat berupa Receiver Merk Sky Box sehingga dapat menangkap siaran pertandingan sepak bola piala Dunia 2018 padahal PT. Bintang Kejora Cable Vision tidak direkomendasikan oleh PT. Digital Vision Nusantara (K-Vision).

\section{Tinjauan Pustaka}

Hak cipta merupakan hak ekslusif pencipta yang timbul secara otomatis setelah suatu ciptaan di umumkan dalam bentuk nyata tanpa mengurangi pembatasan sesuai dengan ketentuan peraturan perundang-undangan. Menurut Pasal 1 ayat (11) UndangUndang Nomor 28 Tahun 2014 tentang Hak Cipta, arti kata mengumumkan merupakan pembacaan, penyiaran, pemeran, suatu ciptaan dengan menggunakan alat apapun baik elektronik maupun non elektronik atau melakukan dengan cara apapun sehingga suatu ciptaan dapat dibaca, didengar, atau dilihat orang lain. ${ }^{4}$

Pencipta adalah seseorang atau beberapa orang secara bersama yang atas inspirasinya melahirkan suatu ciptaan berdasarkan kemampuan pikiran, imajinasi, kecekatan, keterampilan, atau keahlian yang dituangkan dalam bentuk yang khas dan bersifat peribadi. Adapun ciptaan adalah hasil setiap karya pencipta yang menunjukkan keasliannya dalam lapangan ilmu pengetahuan, seni atau sastra. ${ }^{5}$

Menurut Purwosutjipto "hak cipta adalah hak untuk mengumumkan dan untuk memperbanyak ciptaannya". Yang dimaksud dengan pengumuman adalah: pembacaan, penyuaraan, penyiaran, penyebaran suatu ciptaan dengan menggunakan alat apapun, dan dengan cara sedemikian rupa, sehingga suatu ciptaan dapat dibaca, atau dilihat orang lain. ${ }^{6}$

Auteurswet 1912 dalam Pasal (1) menyebutkan "hak cipta adalah hak tunggal dari pencipta, atau hak dari yang mendapat hak tersebut, atas hasil ciptaannya dalam lapangan kesusasteraan, pengetahuan dan kesenian, untuk mengumumkan dan memperbanyak dengan mengingat pembatasan-pembatasan yang ditentukan oleh undang-undang". Kemudian Universal copyright Convention dalam pasal (5) menyatakan "hak cipta meliputi hak tunggal si pencipta untuk membuat, menerbitkan dan memberi kuasa untuk membuat terjemahan dari karya yang dilindungi perjanjian ini. ${ }^{7}$

Menurut Hutauruk ada dua unsur penting yang terkandung dalam pengertian hak cipta yang termuat dalam ketentuan Undang-undang No 28 Tahun 2104 tentang Hak Cipta, yaitu :

1. Hak yang dapat dipindahkan, dialihkan kepada pihak lain.

2. Hak moral yang dalam keadaan bagaimanapun, dan dengan jalan apapun tidak dapat ditinggalkan daripadanya (mengumumkan karyanya, menetapkan judulnya, mencantumkan nama sebenarnya atau nama samarannya dan mempertahankan keutuhan atau integritas ceritanya). ${ }^{8}$

\footnotetext{
${ }^{4}$ Henry Soelistyo, Op cit hal.46.

${ }^{5}$ Abdul R. Saliman dkk, Hukum Bisnis Dan Perusahaan Teori Dan Contoh Kasus Edisi Keenam, Kharisma Putra Utama, 2013, hal 157.

${ }^{6}$ Purwosutjipto, Pengertian Pokok Hukum Dagang Indonesia, Djambatan, Jakarta, 2007, hal, 114.

${ }^{7}$ O.K Saidin, Aspek Hukum Hak Kekayaan Intelektual, Raja Grafindo Persada, 2013, hal 59.

${ }^{8}$ Ibid, hal 60.
} 
Hak yang dapat dipindahkan atau dialihkan itu sekaligus merupakan bukti nyata bahwa hak cipta itu merupakan hak kebendaan. Dalam terminologi Undang-Undang Nomor 28 Tahun 2014 tentang Hak Cipta, pengalihan hanya dapat berupa izin (lisensi) kepada pihak ketiga misalnya untuk karya film dan program komputer, pencipta ataupun penerima hak (produser) berhak untuk memberi izin atau melarang orang lain tanpa persetujuannya menyewakan ciptaan tersebut untuk kepentingan yang bersifat komersil, hal ini yang termasuk dalam hak terkaiit dari hak cipta.

Hak terkait dengan hak cipta (neightboring rights) merupakan hak ekslusif bagi pelaku yang terdiri dari artis film/televise, pemusik, penari, pelawak dan yang lainnya untuk menyiarkan pertunjukannya. Hak cipta dan hak terkait hanya dilanggar jika benda berwujud dari hak terkait misalnya, film,cakram optic,dan pita kaset yang ada hak ciptanya diperbanyak atau digandakan langsung dalam bentuk yang sama dengan benda berwujud yang merupakan ciptaan asli tanpa iziin dari pemegang hak cipta. ${ }^{9}$

Hak terkait dalam Peraturan Pemerintah Nomor 16 Tahun 2020 tentang Pencatatan Ciptaan Dan Produk Hak Terkait adalah hak ekslusif bagi pelaku pertunjukan, produser fonogram, atau lembaga penyiaran. Menurut ketentuan Pasal 20 UU Nomor 28 Tahun 2014 tentang Hak Cipta, hak terkait sebagaimana dimaksud dalam pasal 3 huruf b merupakan hak ekslusif yang meliputi :

a. Hak moral pelaku pertunjukan yang diberi perlindungan tanpa batas waktu (pasal 57)

b. Hak ekonomi pelaku pertunjukan yang diberi perlindungan dan berlaku selama 50 (lima puluh) tahun sejak pertunjukan difiksasi (pasal 63)

c. Hak ekonomi produser fonogram yang diberi perlindungan dan berlaku selama 50 (lima puluh) tahun sejak fonogramnya difiksasi (pasal 63)

d. Hak ekonomi lembaga penyiaran yang diberi perlindungan dan berlaku selama 20 (dua puluh) tahun sejak karya siarnya pertama kali difiksasi (pasal 63)

Secara khusus terhadap perlindungan hak terkait ini, di dalam undang-undang hak cipta memberikan penambahan ancaman pidana bagi pelanggaran hak terkait, di dalam Pasal 72 ayat 2, yaitu :"ancaman pidana dikarenakan kepada baranggsiapa dengan sengaja menyiarkan, memamerkan, mengedarkan, atau menjualsuatu ciptaan atau barang hasil pelanggaran hak terkait, dengan paling banyak Rp500.000.00,00 (lima ratu juta rupiah)". ${ }^{10}$

Menurut Pasal 8 UU No 28 Tahun 2014 tentang Hak Cipta disebutkan "hak ekonomi merupakan hak ekslusif pencipta atau pemegang hak cipta untuk mendapatkan manfaat ekonomi atas ciptaan". Pemanfaatan terhadap hak ekonomi tersebut untuk melakukan penerbitan Ciptaan. Hak ekonomi merupakan hak ekslusif dari pengarang untuk memperoleh keuntungan ekonomi. Hak ekonomi meliputi memperbanyak, hak distribusi, hak pertunjukan, dan hak peragaan. ${ }^{11}$

Menurut Henry Soelistyo Hak ekonomi adalah hak untuk mendapatkan manfaat ekonomi atas ciptaan serta produk hak terkait. Kandungan hak ekonomi meliputi hak untuk mengumumkan (performing rights) dan hak untuk memperbanyak (mechanical rights). Secara umum hak ekonomi meliputi jenis hak, Pertama, hak reproduksi atau pengadaan (reproduction right). Kedua, hak adaptasi (adaption right). Ketiga, hak distribusi (distribution right). Keempat, hak pertunjukan (public performance right). Kelima, hak

\footnotetext{
${ }^{9}$ Lindsey, dkk, Hak Kekayaan Intelektual Suatu Pengantar, Alumni, Bandung, 2011, hal, 102-103.

${ }^{10}$ Sophar Maru Hutagalung, Hak Cipta Kedudukan \& Peranannya Dalam Pembangunan, Sinar Grafika, 2013, hal, 340-344.

${ }^{11}$ Abdul R Saliman dkk, Op Cit, hal, 185.
} 
PATIK : JURNAL HUKUM Vol : 09 No. 3, Desember 2020, Hal 191 - 202

penyiaran (broadcasting right). Keenam, hak programa kabel (cablecasting right). Ketujuh, Droit de suit, dan Kedelapan, hak pinjam masyarakat. ${ }^{12}$

\section{Pengertian Perseroan Terbatas}

Perseroan terbatas atau naamloze Vennootschap diberi pengertian menurut Pasal 1 UU No 40 Tahun 2007 tentang PT adalah "badan hukum yang merupakan persekutuan modal, didirikan berdasarkan perjanjian, melakukan kegiatan usaha dengan modal dasar yang seluruhnya terbagi dalam undang-undang ini serta peraturan pelaksanaannya. ${ }^{13}$ Muhammad Khairandy, Prasetya, dan Purwasujipto berpandangan, bahwa terminologi Perseroan Terbatas, mengandung makna modal yang terdiri atas saham, dan kata terbatas merujuk terbatasnya tanggungjawab pemegang saham pada nilai saham yang dimilikinya. ${ }^{14}$

\section{Organ Perseroan Terbatas}

Menurut Pasal 1 angka 2 UU No 40 Tahun 200t tentang PT, Organ Perseroan Terbatas, terdiri dari Rapat Umum Pemegang Saham (RUPS), Direksi dan Dewan Komisaris. Ketiga organ tersebut melakukan metabolisme tubuh didalam badan hukum PT, menjalankan roda kegiatan PT ke arah visi-misinya. Kegiatan organ-organ tersebut meliputi fungsi pembuatan kebijakan, pelaksanaan, dan pengawasan.

Rapat Umum Pemegang Saham (RUPS) menurut Pasal 1 angka 4 UU No 40 Tahun 2007 tentang PT adalah organ perseroan yang mempunyai wewenang yang tidak diberikan kepada Direksi atau Dewan Komisaris dalam batas yang ditentukan dalam undang-undang ini dan/atau Anggaran Dasar. Pengaturan mengenai RUPS terdapat di dalam Pasal 75 sampai dengan Pasal 91 UU PT No 40 Tahun 2007. Rapat Umum Pemegang Saham adalah rapat yang diselenggarakan oleh Direksi perseroan setiap tahun dan setiap waktu berdasarkan kepentingan perseroan, ataupun atas permintaan pemegang saham sesuai dengan ketentuan Anggaran Dasar kehendak pemegang saham secara bersama-sama dijelmakan dalam suatu keputusan yang dianggap sebagai kehendak perseroan, yang tak dapat ditentang oleh siapapun dalam perseroan, kecuali jika keputusan itu bertentangan dengan maksud dan tujuan perseroan.

Direksi atau disebut juga sebagai pengurus perseroan merupakan alat perlengkapan perseroan yang melakukan semua kegiatan perseroan dan mewakili perseroan, baik didalam maupun diluar pengadilan. Menurut teori organisme dari Otto Von Gierke yang dikutip oleh Suyling "pengurus adalah organ atau alat perlengkapan dari badan hukum. Seperti halnya manusia yang mempunyai organ-organ tubuh misalnya kaki, tangan dan lain sebagainya diperintah oleh otak manusia, demikian pula gerak dari organ badan hukum diperintah olehbadan hukum itu sendiri, sehingga pengurus adalah merupakan personifikasi dari badan hukum itu". ${ }^{15}$

Pasal 79 ayat (2) UU No 40 Tahun 2007 tentang PT menjebutkan secara resmi tugas direksi dalam mengurus perseroan antara lain meliputi pengurusan sehari-hari dari perseroan, yang dimaksud dengan pengurusan sehari-hari lebih lanjut tidak ada penjelasan secara resmi, namun dalam Pasal 82 UU No 40 Tahun 2007 tentang PT memberikan ketentuan sebagai berikut:“Direksi bertanggung jawab penuh atas pengurusan perseroan

\footnotetext{
${ }^{12}$ Ibid, hal, 336.

${ }^{14}$ Habdullah F. Sjawie, Direksi Perseroan Terbatas Serta Pertanggungjawaban Pidana Korporasi, Raja Grafindo, Jakarta,2017, hal 45.

${ }^{15}$ Agus Budiarto, Kedudukan Hukum Tanggung Jawab Pendiri Perseroan Terbatas, Ghalia Indonesia, Jakarta, 2002, hal,61.
} 
untuk keppentingan dan tujuan perseroan serta mewakili perseroan baik didalam maupun diluar pengadilan"

Menurut Undang-Undang No 40 Tahun 2007 Pasal 1 ayat (6), disebutkan bahwa dewan komisaris adalah organ perseroan yang bertugas melakukan pengawasan secara umum dan/atau khusus sesuai dengan anggaran dasar serta memberi nasihat kepada Direksi. Sebagai organ PT, komisaris lazim disebut juga komisaris, sedangkan sebagai orang perseorangan disebut anggota komisaris. Sebagai organ perseroan terbatas pengertian komisaris termasuk juga badan-badan lain yang menjalankan tugas pengawasan khusus dibidang tertentu. ${ }^{16}$

Komisaris pada umumnya bertugas untuk mengawasi kebijaksanaan Direksi, dalam mengurus perseroan serta memberikan nasehat-nasehat kepada Direksi, demikian menurut Pasal 79 UU No 40 Tahun 2007 tentang. Tugas pengawasan itu bisa merupakan bentuk pengawasan preventif atau represif.

Pasal 97 ayat (3) UU No 40 Tahun 2007 tentang PT "setiap anggota Direksi bertanggung jawab penuh secara pribadi atas kerugian Perseroan apabila yang bersangkutan bersalah atau lalai menjalankan tugasnya tersebut" ${ }^{17}$ Peraturan perundangundangan Indonesia mengatur berlakunya Bussines Judgement Rule sebagai bentuk pertanggungjawaban Direksi. Bussines Judgement Rule timbul sebagai akibat telah dilaksanakannya kewajibannya sebagai Direksi dengan penuh tanggung jawab (fiduciary duty). Berlakunya Bussines Judgement Rule menekankan tugas fiduciary duty dari Direksi. yang haruslah memenuhi tiga syarat yuridis yaitu ${ }^{18}$ :
a. Itikad baik.
b. Penuh tanggungjawab.
c. Dan untuk kepentingan Perseroan (proper purpose)

Alvi Syahrin berpendapat, bahwa pertanggungjawaban pidana bagi pejabat korporasi (direksi) yang berada dalam posisi penanggungjawab (pengurus korporasi) berdasarkan Responsible Corporate Officer Doctrine(RCO) dan Strict Liability, ditegaskan bahwa pejabat perusahaan dapat bertanggungjawab atas tindak pidana korporasi, meskipun ia tidak mengetahui adanya tindak pidana tersebut, oleh karena karena posisinya dalam perusahaan memiliki kewajiban untuk mengambil tindakan untuk memastikan bahwa pelanggaran tersebut tidak akan terjadi. ${ }^{19}$

Pejabat korporasi dimintai pertanggungjawaban secara pribadi atas tindak pidana korporasi selama pejabat itu memiliki wewenang untuk mencegah terjadinya pelanggaran atau untuk memperbaiki keadaan. Pertanggungjawaban pidana terhadap pejabat tersebut tidak perlu memperhatikan (dibuktikan lagi) adanya mens rea, sebab mens rea telah terbukti karena pejabat tersebut telah melanggar kewajibannya tersebut. ${ }^{20}$

\section{Metode}

Jenis penelitian yang digunakan adalah penelitian Juridis Normatif. Penelitian Juridis Normatif adalah penelitian yang dilakukan dengan cara menelusuri atau menelaah dan menganalisis bahan pustaka, ketentuan perundang-undangan, putusan pengadilan serta literatur-literatur yang berhubungan dengan pokok bahasan atau bahan dokumen siap pakai sebagai kajian utama.

\footnotetext{
${ }^{16}$ Ibid, hal 70 .

${ }^{17}$ Ibid, hal 22-23.

${ }^{18}$ Sartika Nanda Lestari, Bussines Judgement Rule sebagai Immunity Doctrine Bagi Direksi Badan Usaha Milik Negara Di Indonesia, Jurnal Notarius, ISSBN-2086-1702 (2 September 2015), hal 305-306.

${ }^{19}$ Ibid, hal 7.

${ }^{20}$ Ibid, hal 7.
} 
Metode pendekatan yang digunakan adalah, metode pendekatan perundangundangan (statute approach), yang dilakukan dengan menelaah ketentuan perundangundangan yang berlaku dan terkait dengan isu hukum yang sedang ditangani dan Metode Pendekatan Kasus (case approach). Sumber bahan hukum yang digunakan dalam penulisan ini adalah sumber bahan hukum sekunder terdiri dari data primer berupa bahan hukum yang mempunyai kekuatan hukum mengikat secara umum (perundang-undangan) baik dibidang Hukum Pidana dan Hak Atas Kekayaan Intelektual, data sekunder terdiri dari bahan hukum yang berupa semua publikasi tentang hukum yang bukan merupakan dokumen-dokumen resmi. Publikasi tentang hukum meliputi buku-buku literatur, jurnaljurnal hukum, doktrin, tulisan-tulisan hukum, dari internet yang relevan dengan permasalahan yang dibahas, dan Bahan Hukum Tersier merupakan bahan hukum yang menunjang keterangan dari bahan hukum primer dan hukum sekunder seperti kamus hukum .

\section{Pembahasan Dan Hasil}

Pertanggungjawaban pidana ditujukan untuk menentukan apakah seseorang tersangka/terdakwa dipertanggungjawabkan atas suatu tindak pidana yang terjadi atau tidak. Dalam hal ini apakah terdakwa akan dipidana atau dibebaskan. Jika ia dipidana, harus ternyata bahwa tindakan yang dilakukan itu bersifat melawan hukum dan terdakwa mampu bertanggung jawab. Kemampuan tersebut memperlihatkan kesalahan dari petindak yang berbentuk kesengajaan atau kealpaan artinya tindakan tersebut tercela tertuduh menyadari tindakan yang dilakukan tersebut. ${ }^{21}$

Menurut Roeslan Saleh pertanggungjawaban Pidana: "diartikan sebagai diteruskannya celaan yang objektif yang ada pada perbuatan pidana dan secara subjektif memenuhi syarat untuk dapat dipidana karena perbuatannya itu". ${ }^{22}$ Maksud celaan objektif adalah bahwa perbuatan yang dilakukan oleh seseorang memang merupakan suatu perbuatan yang dilarang. Indikatornya adalah perbuatan tersebut melawan hukum baik dalam arti melawan hukum formil maupun melawan hukum materiil. Sedangkan maksud celaan subjektif menunjuk kepada orang yang melakukan perbuatan yang dilarang tadi. Sekalipun perbuatan yang dilarang telah dilakukan oleh seseorang, namun jika orang tersebut tidak dapat dicela karena pada dirinya tidak terdapat kesalahan, maka pertanggungjawaban pidana tidak mungkin ada. ${ }^{23}$

Suatu perbuatan telah dapat dikatakan melanggar hukum, dan dapat dikenakan sanksi pidana maka harus memenuhi dua unsur yaitu adanya unsur perbuatan pidana yang dalam bahasa asingnya actrus reus dan keadaan sifat batin pembuat yang dalam bahasa asingnya mens rea. Kesalahan atau schuld merupakan unsur pembuat delik, jadi termasuk unsur pertanggungjawaban pidana yang mana terkandung makna dapat dicelanya si pembuat atas perbuatannya. Dalam hal kesalahan tidak terbukti, berarti bahwa perbuatan pidana sebenarnya tidak terbukti, karena tidak mungkin hakim akan membuktikan adanya kesalahan jika ia telah mengetahui lebih dahulu bahwa perbuatan pidana tidak ada atau tidak terbukti diwujudkan oleh terdakwa. ${ }^{24}$

\footnotetext{
${ }^{21}$ Hanafi Amrani dan Mahrus Ali, Sistem Pertanggungjawaban Pidana Perkembangan dan Penerapan, Cet. I, Rajawali Pers, Jakarta, 2015, hal. 21

${ }^{22}$ Roeslan Saleh, Perbuatan Pidana dan Pertanggungjawaban Pidana; Dua Pengertian Dasar Dalam Hukum Pidana, Cetakan Ketiga, Aksara Baru, Jakarta, 1983, hal. 20-23.

${ }^{23}$ Hanafi Amrani dan Mahrus Ali, Sistem Pertanggungjawaban Pidana Perkembangan dan Penerapan, Cet. I, Rajawali Pers, Jakarta, 2015 hal 21.

${ }^{24}$ Andi Zainal Abidin,, Asas-Asas Hukum Pidana Bagian Pertama, Alumni, Bandung, 1987, hal . 72.
} 
Duduk Perkara Putusan No. 193/Pid.Sus/2019/PN. Tarnate sebagai berikut :

Terdakwa Ir. Muhammada Bachmid MBA alias Aba selaku Direktur Utama (DIRUT) PT. Bintang Kejora Cable sebagai lembaga Penyiaran Berlangganan (LBP) Televisi Kabel berdasarkan ijin penyelenggara penyiaran dari Menteri Komunikasi dan Informatika Republik Indonesia Nomor :189/T.04.02/2018 tanggal 11 April 2018 dan Akta Pendirian Notaris Nomor : 58 tanggal 23 Juni 2011 serta Pengesahan Badan Hukum Perseroan Departemen Hukum dan Hak Asasi Manusia (DEPKUMHAM) RI Nomor : AHU-39771.ah.01.01 tahun 2011 tentang pengesahan Badan Hukum Perseroan untuk melakukan kegiatan usaha dibidang penyiaran berlangganan (Televisi Kabel) kepada masyarakat.

Dalam usahanya dibidang penyiaran berlangganan (Televisi Kabel) kepada masyarakat di Kota Ternate, terdakwa melakukan kegiatan usaha dibidang penyiaran berlangganan (Televisi Kabel) sejak bulan Juni 2011 dengan jumlah langganan/ pelanggan sebanyak 1.150 (seribu seratus lima puluh) langganan/ pelanggan untuk rumah tempat tinggal, hotel maupun perkantoran dengan memasang tarif/ iuran langganan bulanan setiap bulan sebesar Rp.40.000,-(empat puluh ribu rupiah).

Sesuai dengan Ijin yang dikeluarkan oleh Menteri Komunikasi dan Informatika terhadap usaha Penyiaran Berlangganan (LBP) Televisi Kabel kepada PT. Bintang Kejora Cable Vision terbatas kepada 45 (empat puluh lima) konten Penyiaran tidak termasuk penyiaran yang di tayangkan melalui perhelatan sepak bola piala dunia oleh karena itu apabila ia terdakwa menyiarkan konten sepakbola piala dunia melalui Televisi Kabel Bintang Kejora Cable Vision miliknya kepada masyarakat terlebih dahulu memintakan ijin persetujuan hak siar kepada PT. Digital Vision Nusantara di Jakarta.

Terdakwa melakukan penayangan siaran dan siaran ulang konten sepakbola piala dunia tahun 2018 sejak tanggal 15 Juni 2018 sampai dengan tanggal 15 Juli 2018 melalui Televisi Kabel Bintang Kejora Cable miliknya kepada masyarakat/ pelanggannya akan tetapi ia terdakwa tidak meminta ijin hak siar kepada PT. Digital Vision Nusantara padahal ia tahu apabila melakukan penayangan perhelatan sepak bola piala dunia harus terlebih dahulu meminta ijin komersial kepada PT. Digital Vision Nusantara.

Televisi Kabel Bintang Kejora Cable Vision pada saat siaran pertandingan bola piala dunia tahun 2018 dimulai akan tetapi mengalami gangguan sehingga menggunakan antena UHF (siaran Trans TV dan Trans 7) selama 3 (tiga) hari dari pembukaan piala dunia sepak bola akan tetapi mendapat informasi/ pemberitahuan tentang larangan menyiarkan secara komersial kepada masyarakat pertandingan sepak bola piala dunia dari Trans TV dan Trans 7), oleh karena itu ia terdakwa bermaksud menyiarkan secara komersial kepada masyarakat pelanggannya maka ia terdakwa lalu menggunakan alat berupa Reciver merk Sky Box sehingga dapat menangkap siaran pertandingan sepakbola piala duani tahun 2018 .

Terdakwa sebelumnya tidak memiliki alat berupa Reciver merk Sky Box, oleh karena itu ia terdakwa ingin menayangkan secara komersial kepada masyarakat pelanggan Televisi Kabel miliknya sehingga ia terdakwa membeli alat berupa Reciver Sky Box dengan harga sebesar Rp.650.000,- (enam ratus lima puluh ribu rupiah), dan dengan menggunakan Reciver tersebut guna menangkap satelit Intel Sat 19 Chanel Liga (siaran Philipina) sehingga Televisi Kabel Bintang Kejora Cable Vision dapat menangkap siaran langsung maupun siaran ulang pertandingan sepak bola piala dunia 2018, padahal Televisi Kabel Bintang Kejora Cable Vision tidak direkomendasikan/ tidak memiliki ijin oleh PT. Digital Vision Nusantara sebagai pemegang Lisensi.

Berdasarkan Perjanjian Sublisensi Hak Media tertanggal 07 November 2017, PT. Digital Vision Nusantara (K-Vision), FMA secara penuh mengakui $K$-Vision sebagai SubLisensi yang berhak atas Hak Media untuk Platform Satelit. Selanjutnya, berdasarkan 
persetujuan atas Mode Eksploitasi Keuntungan dan Model Bisnis yang disampaikan kepada FMA oleh $K$-Vision dan mendapat persetujuannya, K-Vision dianggap sebagai Penyiar satelit tunggal untuk World Cup 2018 Russia dengan Sublisensi untuk mode eksploitasi keuntungan Prepaid dan/atau Penjualan STB sejak 23 Maret 2018.

Bahwa berdasarkan Perjanjian Hak Media tertanggal 22 November 2017, sebagai bagian dari PT. Trans Media Corpora (Transmedia), FMA secara penuh mengakui TransVision (TransVision) sebagai sub-lisensi yang berhak atas hak parsial untuk Platform Satelit. Selanjutnya berdasarkan persetujuan atas Mode Eksploitasi Keuntungan dan Model Bisnis yang disampaikan kepada FMA oleh TransVision dan mendapatkan persetujuannya, TransVision dianggap sebagai penyiar satelit tunggal untuk World Cup Rusia dengan sublisensi untuk mode eksploitasi keuntungan Post-Paid Berlangganan. Bahwa selain dari KVision dan TransVision, tidak ada sub-lisensi penyiaran satelit lain untuk FMA pada saat ini dan kepatuhan akandi monitor dan dilaksanakan sebagai perioritas untu $\mathrm{k}$ melindung kepentingan terbaik dari pemegang Lisensi Hak Media lain yang sah dan FMA sedemikian.

Bahwa berdasarkan Addendum to Media Rights Sublicensing, tanggal 22 Mei 2018 perihal penambahan terhadap Perjanjian Sublisensi Hak Media (Perjanjian) yang dibuat pada tanggal 22 Mei 2018, antara PT. Futbal Momentum Asia (FMA) sebagai Lisensor dan PT. Digital Vision Nusantara sebagai Licensee. Pasal 2 Amandemen huruf A butir 1.3. berbunyi: dengan tetap menggantung kepada larangan, pembatasan dan kewajiban yang diatur dalam perjanjian sublisensi Hak Media dan seluruh hukum yang berlaku pada teritori dari waktu ke waktu, licensor dengan ini menambahkan hak lisensee sebuah sublisensi terhadap hak untuk melakukan redistribusi, menyediakan feed bersih serta mengembangkan dan mengeksekusi perjanjian platfom redistribusi dengan platfom kabel dan operator, operator kabel lokal, secara khusus, diteritori selama periode hak. Dan berdasarkan Surat Penunjukan kepada PT. Digital Vision Nusantara, tanggal 22 Mei 2018 perihal pemberian mandat untuk perluasan platfom hak ke platfom TV kabel.

Majelis Hakim telah mengambil keputusan, dengan memperhatikan apakah perbuatan terdakwa memenuhi unsur-unsur Pertanggungjawaban Pidana berdasarkan bentuk Kesalahan antara lain:

1. Setiap orang

Setiap orang dalam unsur ini adalah siapa saja sebagai subyek hukum atau pelaku perbuatan yang dapat dimintai pertanggungjawabannya terhadap perbuatan yang dilakukan apabila perbuatan tersebut mempunyai akibat hukum. Kata setiap orang identik dengan terminologi kata "barangsiapa" atau dengan pengertian siapa saja yang harus dijadikan terdakwa atau setiap orang sebagai subyek hukum (pendukung hak dan kewajiban) yang dapat diminta pertanggungjawaban dalam segala tindakannya sehingga secara historis manusia sebagai subyek hukum telah dengan sendirinya ada kemampuan bertanggungjawab kecuali secara tegas undang-undang menentukan lain. Dalam putusan terdakwa (Ir. Muhammada Bachmid MBA alias Aba) merupakan subyek hukum yaitu Direktur PT. Digital Vision Nusantara.

2. Unsur dengan sengaja dan tanpa hak melakukan pelanggaran hak ekonomi

Sengaja sebagai kemungkinan (dolus eventualis) adalah kesadaran pelaku mengenai kemungkinan terjadinya suatu tindakan dan akibatnya. Kesengajaan sebagai maksud (oogmerk) adalah terjadinya suatu tindakan atau akibat tertentu yang sesuai dengan perumusan undang-undang hukum pidana adalah betul-betul sebagai perwujudan dari maksud atau tujuan dan pengetahuan pelaku. Kesengajaan dengan kesadaran pasti atau 
keharusan (Opzet bij zekerheids of noodzakelijkheids bewustzijn) adalah seberapa jauh pengetahuan atau kesadaran pelaku tentang tindakan dan akibat yang merupakan salah satu unsur dari pada suatu delik yang telah terjadi dalam hal ini termasuk tindakan atau akibatakibat lainnya yang pasti / harus terjadi.

Sebagaiamana yang dimaksud dengan Hak ekonomi adalah merupakan hak eksklusif Pencipta atau Pemegang Hak Cipta untuk mendapatkan manfaat ekonomi atas Ciptaan. Dan melanggar hak siar dalam ketentuan UU Nomor 28 Tahun 2014 tentang Hak Cipta bahwa kata hak Siar tidak dikenal namun yang dikenal adalah karya siaran. Karya siaran merupakan produk dari hak ekonomi yang dihasilkan oleh Lembaga Penyiaran.

Pengadilan Negeri Tarnate dalam memutuskan perkara ini sebagaimana fakta-fakta persidangan yaitu terdakwa Muhammada Bachmid MBA alias Aba melakukan penyiaran ulang baik langsung maupun tidak langsung konten siaran piala dunia 2018 (FIFA World Cup 2018 Rusia) dengan cara merelai siaran dari luar negeri "Liga Filipina", boleh dilakukan namun hanya untuk kepentingan pribadi semata namun apabila disalurkan kepada para pelanggannya dengan memungut biaya, sedangkan patut diketahui bahwa pemilik hak penyiaran di wilayah NKRI adalah PT. Futbal Momentum Asia (FMA) selaku pemegang lisensi yang telah disublisensikan kepada PT. Digital Vision Nusantara $(K-$ Vision).

Tindak pidana hak cipta tidak berlaku bagi pelaku yang beritikad baik memperoleh ciptaan semata-mata untuk kepentingan diri sendiri dan tidak untuk suatu kegiatan komersial atau kepentingan yang berkaitan dengan kepentigan komersial, oleh sebab itu penulis memperhatikan pada kasus tindak pidana ini berupa kepentingan komersial, pada umumnya dilatarbelakangi untuk memperoleh keuntungan. Dalam kasus ini terdakwa akan memperoleh keuntungan yang tidak wajar.

Penulis menilai adanya suatu sinergi antara jaksa dengan hakim, sebagaimana antara dakwaan yang memenuhi seluruh unsur perbuatan terdakwa, dan tuntutan yang tegas, beserta putusan oleh hakim yang memutus terhadap terdakwa pidana penjara selama satu (1) tahun enam (6) bulan dan dikenakan denda sejumlah Rp 1.000.000.000 (satu milyar rupiah) dalam hal ini penulis menilai hakim memutus perkara dengan pertimbangan keadaan yang meringankan, dan keadaaan yang memberatkan terdakwa, dan melalui musyawarah.

Dalam perkara ini Penuntut Umum menghadapkan Terdakwa Ir. Muhammad Bachmid, MBA Alias Aba dengan identitas yang sama seperti yang tercantum dalam surat dakwaan, Terdakwa menerangkan bahwa benar apa yang di maksud oleh Penuntut Umum didalam surat dakwaan, selain itu selama proses persidangan Terdakwa dalam keadaan sehat baik jasmani maupun rohani, oleh karena itu Terdakwa dipandang mampu bertanggungjawab terhadap perbuatan yang dilakukan. Ir. Muhammad Bachmid, MBA Alias Aba mengakui bahwa ia telah melanggar UU Nomor 28 Tahun 2014 tentang Hak Cipta. Didalam fakta persidangan terdakwa terbukti melakukan perbuatan mengambil siaran Piala Dunia Rusia 2018 tersebut melalui free to air dari stasiun Liga Philipina dengan bantuan alat Receiver Merk Sky Box.

Penjatuhan hukuman pidana yang dilaksanakan di lembaga pemasyarakatan sebagai eksekutor dari putusan pengadilan tidak akan memberi efek jera kepada pelaku pelanggaran hak cipta, hukuman pidana hanya akan memberikan pelaku pelajaran kepada terdakwa untuk menjaadi seseorang yang lebih jahat.

Pelanggaran hak cipta dari kejahatannya tidak memberikan penderitaan fisik bagi korban dan bagi terdakwa pun tidak melakukan kontak fisik bagi korbannya apalagi melakukan kekerasan hanya saja kejahatan hak cipta ini merugikan korbannya secara 
ekonomi baik bagi pemilik ciptaan bahkan negara sehingga dengan alasan ini penulis tidak setuju apabila dijatuhkan pidana penjara yang lama.

Putusan 193/Pid.Sus/2019/PN Tte sudah dianggap cukup hukuman ini dianggap telah memperhatikan aspek korban dan aspek pelaku dimana korban dirugikan secara materil yaitu kerugian berupa hak ekonomi yang dilanggar sehingga hakim memutus berupa pidana dan denda

Terhadap tindak pidana Hak Kekayaan Intelektual ada 3 (tiga) teori dasar diadakan hukuman terhadap pribadi orang yang melakukan pelanggaran atau tindak pidana Hak Kekayaan Intelektual, yakni

1. Teori imbalan (Absolute/Vergeldingstheorie)

2. Teori maksud atau Tujuan (Relative/doeltheorie)

3. Teori gabungan (Verenigingstheorie)

Dalam Putusan 193/Pid.Sus.2019/ PN Tte telah menggunakan teori teori gabungan. Sebagaimana teori gabungan mengajarkan penjatuhan hukuman untuk mempertahankan tata tertib masyarakat dan memperbaiki pribadi si penjahat, dengan teori ini terdapat tujuan pemidanaan adalah: Pertama: Menjerakan penjahat, Kedua: Membinasakan atau membuat tak berdaya lagi si penjahat, Ketiga : Memperbaiki diri si penjahat pada hakikatnya, ketiga hal tersebut menjadi dasar diadakannya sanksi pidana.

Terdakwa dalam perkara ini walaupun merupakan Direktur Utama Perseroan

Terbatas (PT Bintang Kejora Cable) dituntut dan diputus di pengadilan negeri Tarnate dalam perkara tindak pidana hak cipta secara perseorangan dan perbuatan terdakwa sepenuhnya menjadi tanggungjawabnya sendiri karena perbuatan ini merupakan murni serangkaian dari tindakan yang dilakukan oleh Ir. Muhammad Bachmid, MBA alias Aba.

Penulis berpendapat dikarenakan kasus pelanggaran hak ekonomi ini merupakan delik aduan yang hanya dapat diproses apabila diadukan oleh orang yang merasa dirugikan atau telah menjadi korban, dalam delik aduan ini penuntutan digantungkan pada persetujuan dari yang dirugikan maka terhadap kasus pelanggaran hak ekonomi siaran piala Dunia 2018, terdakwa dilaporkan oleh pemilik lisensi siaran dan bukan korporasi karena perbuatan ini bukan merupakan perbuatan korporasi dan hanya menguntungkan terdakwa semata.

Dikaitkan Terdakwa sebagai direksi dapat mempertanggungjawabkan perbuatan pidananya menggunakan teori pertanggungjawaban Business Judment Rules. Direksi bertanggungjawab atas kerugian Perseroan yang diakibatkan kesalahan atau lalai dalam tugas direksi dalam pengadilan Pidana ini sesuai dengan amar putusan hakim hanya membebankan pidana kepada terdakwa Ir. Muhammad Bachmid, MBA alias Aba.

Tindak pidana ini terjadi atas kesalahan yang dilakukan oleh Direksi, untuk membebankan pertanggungjawaban terhadap direktur atau pengurus korporasi, maka harus dibuktikan adanya pelanggaran terhadap kekuasaan kewajiban kewenangan yang dimilikinya. Pengurus korporasi dalam hal ini harus dapat dibuktikan bahwa Direktur PT telah melanggar good faith yang dipercayakan padanya dalam menjalan korporasi atau perusahaan, sebagaimana diatur dalam prinsip fiduciary duty. Dalam fakta-fakta di persidangan sangat jelas dan bahkan terdakwa mengakui perbuatannya di muka pengadilan, maka hal ini menjadi alasan Direktur PT untuk mempertanggungjawabkan perbuatan pidana.

\section{Kesimpulan dan Saran}

Pejabat korporasi dapat dimintai pertanggungjawaban secara pribadi atas tindak pidana dimuat dalam peraturan perundang-undangan Indonesia dengan prinsip Bussines 
Judgement Rule sebagai akibat tidak dilaksanakannya kewajibannya sebagai Direksi dengan penuh tanggung jawab (fiduciary duty).

Perlu adanya dikenalkan kepada masyarakat penghargaan dan pengakuan terhadap Hak Kekayaan Intelektual karena hal ini akan memberi dampak sangat baik bagi kesadaran hukum masyarakat.

\section{DAFTAR PUSTAKA}

\section{Buku}

Andi Zainal Abidin,, Asas-Asas Hukum Pidana Bagian Pertama, Alumni, Bandung, 1987, hal . 72.

Abdul R. Saliman dkk, Hukum Bisnis Dan Perusahaan Teori Dan Contoh Kasus Edisi Keenam, Kharisma Putra Utama, 2013, hal 157.

Agus Budiarto, Kedudukan Hukum Tanggung Jawab Pendiri Perseroan Terbatas, Ghalia Indonesia, Jakarta, 2002, hal,61.

Habdullah F. Sjawie, Direksi Perseroan Terbatas Serta Pertanggungjawaban Pidana Korporasi, Raja Grafindo, Jakarta,2017, hal 45.

Hanafi Amrani dan Mahrus Ali, Sistem Pertanggungjawaban Pidana Perkembangan dan Penerapan, Cet. I, Rajawali Pers, Jakarta, 2015, hal. 21

Henry Soelistiyo, Hak Cipta Tanpa Hak Moral, Jakarta, Grafindo, 2011

Lindsey, dkk, Hak Kekayaan Intelektual Suatu Pengantar, Alumni, Bandung, 2011, hal, 102-103.

O.K Saidin, Aspek Hukum Hak Kekayaan Intelektual, Raja Grafindo Persada, 2013, hal 5

Purwosutjipto, Pengertian Pokok Hukum Dagang Indonesia, Djambatan, Jakarta, 2007, hal, 114.

Rahmi Janed Perinduri Nasution, Interface Hukum Kekayaan Intelektual dan Hukum Persaingan Penyelahgunaan HKI, Jakarta, Grafindo, 2013

Roeslan Saleh, Perbuatan Pidana dan Pertanggungjawaban Pidana; Dua Pengertian Dasar Dalam Hukum Pidana, Cetakan Ketiga, Aksara Baru, Jakarta, 1983.

Simamora, Janpatar., Tafsir Makna Negara Hukum dalam Perspektif Undang-Undang Dasar Negara Republik Indonesia Tahun 1945, Jurnal Dinamika Hukum FH Universitas Jenderal Soedirman, Vol. 14 No. 3 September 2014.

Sophar Maru Hutagalung, Hak Cipta Kedudukan \& Peranannya Dalam Pembangunan, Sinar Grafika, 2013, hal, 340-344

\section{Internet}

Andry Novelindo, Pelanggaran Merek Paling Banyak Diadukan ke kemenkumham.Com, 1 Januari 2020, Diakses, tgl 13 Mei 2021 dilaman http://m.cnnindonesia.com/tehnologie/20191231141341-185-461331/pelanggaran-merekpaling-banyak-diadukan-ke-kemenkumham 